\title{
LEGALIZATION OF BITCOIN CRYPTOCURRENCY. PRIVATE LAW ASPECTS
}

\author{
LEgALIZACJA KRYPTOWALUTY BitCOIN. \\ ASPEKTY CYWILNOPRAWNE
}

\begin{abstract}
The emergence of a cryptocurrencies in the economic circulation is a challenge for legal systems. The response of a legal system depends on social, political and international determinants. The first attempts to understand cryptocurrencies usually concerns tax law, which, however, are related to the civilian understanding of the phenomenon. In the Polish legal system, we had a lack of regulation directly related to cryptocurrencies, which caused them to be strictly qualified as an instrument whose exchange for money was not exempt from VAT as Bitcoin was not classified as money. This situation has changed as a result of the case law of the Court of Justice of the European Union, which has recognized Bitcoin as an alternative means of payment. Recently, new statutory regulations have been introduced in non-European legal systems, i.e. in Japan and Arizona, which regulate cryptocurrencies in a wider way. This allows us to propose classification of legal systems based on the relationship they have towards cryptocurrencies.
\end{abstract}

\section{STRESZCZENIE}

Pojawienie się w obrocie gospodarczym kryptowalut jest wyzwaniem dla systemów prawnych, których reakcja zależy od uwarunkowań społecznych, politycznych i międzynarodowych. Pierwsze próby ulokowania kryptowalut zwykle dotyczyły kwalifikacji podatkowej, która jednakże jest związana z cywilistycznym rozumieniem zjawiska. Na gruncie polskiego systemu prawnego do czynienia mieliśmy z brakiem regulacji wprost odnoszącej się do kryptowalut, który powodował ścisłe ich 
kwalifikowanie jako instrumentu, którego wymiana na pieniądze nie jest zwolniona z VAT ze względu na to, że Bitcoin był kwalifikowany jako pieniądz. Sytuacja ta uległa zmianie w wyniku orzecznictwa Trybunału Sprawiedliwości Unii Europejskiej, który uznał jednostki Bitcoin za alternatywny środek płatniczy. W ostatnim czasie pojawiły się także nowe regulacje rangi ustawowej w pozaeuropejskich systemach prawnych, tj. w Japonii i w Arizonie, które w szerszy sposób regulują problematykę kryptowalut. Pozwala to na zaproponowanie klasyfikacji systemów prawnych ze względu na to, jaki stosunek mają do posiadania i obrotu kryptowalutami.

KEYWORDS: cryptocurrency, Bitcoin, private law, Bitcoin legalization

SŁowa KLUCzowe: kryptowaluta, Bitcoin, prawo cywilne, legalizacja Bitcoin

\section{WPROWADZENIE}

Każda tradycja prawna spotyka się cyklicznie z nowymi wyzwaniami, które swoje źródło mają w kreatywności człowieka i nieprzewidywalnych procesach społecznych. Rewolucja gospodarczo-kulturowa związana z postępem technologicznym głównie w dziedzinie transportu i komunikacji na odległość, która doprowadziła do homogenizacji kulturowej, zmniejszenia znaczenia koncepcji państwa narodowego i wzrostu współzależności gospodarek nazywana jest globalizacją. Globalizacja wywarła silny wpływ na systemy prawne, doprowadzając do wykształcenia ruchów unifikacyjnych i ponadnarodowych organizacji (por. Sitek, 2016, s. 112 i n.). Kolejna rewolucja ekonomiczna ma bardziej subtelny charakter i związana jest $\mathrm{z}$ obrotem informacją, która nie tylko przesyłana jest na odległość, lecz przede wszystkim przetwarzana za pomocą zaawansowanych algorytmów pozwalających ukrywać przesyłane i przechowywane informacje przez ich szyfrowanie oraz zapewniać ich uwierzytelnianie i integralność. Możliwe jest to ze względu na wzrost dostępnej mocy obliczeniowej, zwiększenie przepustowości sieci teleinformatycznych oraz doskonalenie i otwartość algorytmów przetwarzania danych. Istotnym czynnikiem jest tu także doskonalenie interfejsów komputerowych, co zwiększa ich przyjazność dla użytkowników oraz wzrost umiejętności posługiwania się komputerami w społeczeństwach.

Postęp technologiczny w różnych dziedzinach często jest obrazowany za pomocą dość banalnych porównań między dostępnością zasobów dla czło- 
wieka w danym okresie historycznym i współcześnie. Wskazuje się często, że w dziedzinie transportu osoba zamożna mogła jeszcze dwa wieki temu dysponować co najwyżej kilkoma końmi, dzisiaj zaś osoba zamożna dysponuje mocą setek koni, osoba przeciętnie zamożna - dziesiątek koni. Kolejnym często spotykanym porównaniem jest przytaczanie mocy obliczeniowej komputera obsługującego pojazd misji Apollo 11, którego pamięć miała 160 kilobajtów, a wykonywał około 40 tys. operacji na sekundę, które to liczby są o kilka rzędów wielkości mniejsze niż te, którymi dysponuje dzisiaj dziecko bawiące się smartfonem. W dziedzinie istotnej z punktu widzenia niniejszego tekstu, czyli kryptologii, można zauważyć, że obecnie każdy użytkownik smartfonu lub komputera dysponuje narzędziami zapewniającymi wielokrotnie szybsze, wielokrotnie skuteczniejsze i wielokrotnie łatwiejsze w użyciu szyfrowanie i deszyfrowanie danych, niż dysponowały najlepsze armie czasu II wojny światowej. Wraz z postępującą globalizacją i liberalizacją gospodarki zanikły granice dla działalności inwestycyjnej na świecie. Ponadnarodowy transfer kapitałów, wiedzy i pracy jest procesem ciągłym, z tendencją rozwoju zarówno pod względem skali, jak i pod względem geograficznym (Włodarczyk, 2014).

Jednym z budzących największe kontrowersje i rodzących najtrudniejsze pytania osiągnięć technicznych ostatnich lat jest kryptowaluta - narzędzie, którego cechy pozwalają na transfer kapitału ponad granicami państw i jednocześnie sprawiając duże trudności w kontroli tych transferów przez państwo. Koncepcja ta powstała w pierwszym dziesięcioleciu XXI wieku i została finalnie opracowana technicznie przez Satoshi Nakamoto (Nakamoto, 2008). Nie ma pewności co do tego, czy Satoshi Nakamoto to pseudonim, prawdziwe imię i nazwisko, czy też grupa ludzi. Trafnie więc Mariański określa Satoshi Nakamoto jako podmiot (Mariański, 2015, s. 92) - wszak niezależnie od tego, czy jest to jeden człowiek czy ich grupa, to Satoshi Nakamoto jest podmiotem praw do systemu kryptowalutowego nazwanego Bitcoin. Niniejszy tekst zmaga się z pytaniem o skutki różnych stopni legalizacji kryptowaluty Bitcoin dla systemu prawnego, w szczególności ze względu na niedawne zalegalizowanie obrotu przez Japonię oraz Arizonę (Arizona House Bill 2417 an Act Amending Section 44-7003, Arizona Revised Statutes; Amending Title 44, Chapter 26, Arizona Revised Statutes, by Adding Article 5; Relating 
to Electronic Transactions z dnia 29 marca 2017 r.), co rodzi pytanie o wpływ takiej legalizacji na obrót międzynarodowy, a także może być zwiastunem zmiany podejścia przez inne państwa. Tytułowa legalizacja jest traktowana w niniejszym tekście jako pojęcie stopniowalne, które w różnych odcieniach znaczeniowych może oznaczać:

1) niekaralność wytwarzania, posiadania lub obrotu, przy jednoczesnej nieważności czynności obrotu handlowego z ich wykorzystaniem,

2) milczenie prawa w przedmiocie obrotu i posiadania kryptowalut, co rodzi niepewność uczestników obrotu w zakresie przysługującej im ochrony prawnej,

3) uznanie kryptowalut za środek płatniczy, podlegający ochronie na tych samych zasadach co tradycyjne środki płatnicze.

W świetle powyższego nielegalność należy zdefiniować jako prawnokarny zakaz wytwarzania, posiadania i obrotu kryptowalutami. W ramach obu pojęć możliwe są oczywiście także odcienie znaczeniowe, nie są bowiem wykluczone w przypadku wyłączenia z obrotu, ale dopuszczenia posiadania wartości majątkowych - stąd nie można wykluczyć rozwiązań prawnych będących na pograniczu wymienionych stopni legalizacji. W zasadzie, poza przypadkiem nielegalności i legalności ograniczającej się do niekaralności, ale powiązanej z brakiem ochrony cywilnoprawnej, można mówić o zjawisku regulacji kryptowalut. Zdecydowałem się jednak objąć wszystkie powyżej wymienione odcienie znaczeniowe słowem „legalizacja”, a nie „regulacja”, ze względu na ogromne znaczenie przeskoku między brakiem regulacji a chociażby szczątkową regulacją dla uczestników obrotu. Milczenie prawa w kwestiach dotyczących obrotu gospodarczego często związane jest z trudnościami interpretacyjnymi. Przykładem takich trudności może być uchylenie przepisów o spółce cichej, które doprowadziło do ożywionej dyskusji nad charakterem prawnym spółek, w których wola stron odpowiada treści uchylonych przepisów o spółce cichej, jednakże brak norm zmusza na nowo doktrynę i organy stosujące prawo do rozważań nad skutkiem normatywnym zawartej przez wspólników umowy spółki (Ciućkowska-Leszczewicz, 2013, s. 218 i n.).

Kryptowaluta Bitcoin stanowi wyzwanie dla wszystkich dojrzałych kultur prawnych. Problematyczne przede wszystkim są te aspekty obrotu, które 
tworzą ryzyka prawne i społeczne. Za przykład może posłużyć tu niechlubna platforma wymiany nielegalnych dóbr, usług, a nawet handlu ludźmi zwana silk road, w ramach której dokonywano zapłaty jednostkami Bitcoin. Kolejnym przykładem była giełda wymiany jednostek Bitcoin Mt. Gox, w trakcie działania której „zagubiono” około 850000 jednostek Bitcoin (około 480000000 USD, dane za Bloomberg Technology). W literaturze wskazuje się także na zagrożenia związane z możliwością unikania opodatkowania za pomocą kryptowalut (Marian, 2013). Mimo tych problemów stosunkowo niewiele państw zdecydowało się zakazać obrotu kryptowalutą Bitcoin (Boliwia, Ekwador, Kirgistan, Bangladesz). Wydaje się, że istnieją dwa główne argumenty przemawiające za akceptacją kryptowalut. Po pierwsze, nie jest jeszcze w pełni znany zakres korzyści ekonomicznych, jakie mogą one przynieść społeczeństwu. Po drugie, problemy związane z przestępczym wykorzystaniem kryptowalut nie są obce tradycyjnie używanym walutom, tj. pieniądzowi państwowemu. Na marginesie należy wspomnieć, że pod pewnymi względami kryptowaluty zapewniają lepsze niż pieniądz papierowy możliwości wykrywania przestępstw ze względu na zapisywanie transakcji w publicznie dostępnym rejestrze.

W niniejszym artykule zastosowano metodę formalno-dogmatyczną.

\section{ASPEKTY TECHNICZNE OBROTU KRYPTOWALUTĄ BITCOIN}

W rozwoju historycznym wartość pieniądza związana była z wartością kruszcu, z jakiego pieniądz ten był wykonany. Pieniądz wykonany z kruszcu był częściowo niepraktyczny, łatwo było go bowiem podrobić np. przez wytworzenie stopu złota $\mathrm{z}$ tańszym pierwiastkiem w miejsce pieniądza wykonanego z czystego złota. Aby zabezpieczyć się przed kradzieżą pieniądza kruszcowego, uczestnicy obrotu składali taki pieniądz do przechowania w zamian za pokwitowanie; pokwitowania (noty bankowe) były następnie używane zamiast pieniądza kruszcowego w obrocie. Rozpoczęło to proces dematerializacji pieniądza. Następną fazą rozwoju pieniądza było stworzenie pieniądza fiducjarnego, czyli takiego, który nie posiadał oparcia w kruszcu. Gwarantem pewności jego wartości jest państwo, które realizuje politykę pieniężną (Luo, 1998, s. 416 i n.; Mittal, 2012, s. 5). 
Atrakcyjność kryptowaluty Bitcoin dla obrotu związana jest z tym, że zapewnia ona pewność obrotu - wpisaną w założenia systemu przez zastosowanie sieci rozproszonej i technologii łańcucha bloków - która to pewność obrotu przed wynalezieniem kryptowalut wymagała udziału osób trzecich oraz interwencji państwa (Nakamoto, 2008, sekc. 5).

System Bitcoin działa za pośrednictwem sieci internet. Włączenie do systemu pozbawione jest ograniczeń podmiotowych. Każdy posiadający umiarkowanie nowoczesny komputer może uczestniczyć w wytwarzaniu i obracaniu jednostkami Bitcoin, pobierając i instalując darmowe oprogramowanie. Po włączeniu do systemu Bitcoin komputer staje się „węzłem generującym”, co oznacza, że poświęca swoją moc obliczeniową na funkcjonowanie systemu jako całości, w zamian za co, z pewnym prawdopodobieństwem może być mu przyznana przez system jednostka Bitcoin; ma to stanowić zachętę ekonomiczną do udostępniania mocy obliczeniowej w systemie Bitcoin (Nakamoto, 2008, sekc. 5).

Działalność polegająca na udostępnianiu mocy obliczeniowej w celu pozyskania jednostek Bitcoin nazywana jest „kopaniem” („Bitcoin mining”). Węzły generujące przechowują całość transakcji dokonanych w systemie od początku jego istnienia. Baza danych, w której przechowywane są dane o transakcjach, nazywana jest łańcuchem bloków. Wyjątkowość tej bazy danych polega na zapisywaniu danych (w przypadku łańcucha bloków Bitcoin - danych o transakcjach) w następujących po sobie czasowo blokach, z których każdy kolejny zawiera także skrót kryptograficzny poprzedniego bloku. Powoduje to praktyczną całkowitą integralność danych i nieodwracalność transakcji w systemie - sfałszowanie łańcucha bloków wymagałoby bowiem tak dużej mocy obliczeniowej, że bardziej opłacalne jest poświęcić ją na „granie według zasad” (Nakamoto, 2008, sekc. 6). Dokonywanie transakcji w systemie Bitcoin dokonywane jest za pomocą tzw. kryptografii klucza publicznego. Polega to na podpisywaniu transakcji wychodzących z danego portfela Bitcoin (ang. Bitcoin wallet) kluczem prywatnym. Weryfikacja prawdziwości transakcji możliwa jest natomiast na podstawie klucza publicznego - w tym przypadku kluczem publicznym jest sama nazwa portfela Bitcoin.

Z punktu widzenia osoby chcącej jedynie korzystać z jednostek Bitcoin jako środka płatności możliwe jest korzystanie z jednej z wielu platform obrotu na 
podstawie umowy cywilnoprawnej. W ramach tego stosunku platformy obrotu umożliwiają wymianę innych walut na jednostki Bitcoin, a także udostępniają portfel, w którym przechowywane są środki klienta. Taki sposób korzystania z kryptowaluty związany jest z koniecznością zaufania platformie obrotu, co różnicuje go znacznie w stosunku do korzystania z kryptowaluty bezpośrednio, gdzie zaufanie jest zapewniane przez algorytmy kryptograficzne.

Kolejną kwestią poruszaną w dyskusji o kryptowalutach jest problem anonimowości. W założeniu Bitcoin miał być elektroniczną gotówką, czyli bezpośrednim i anonimowym sposobem płatności. Wątpliwości co do anonimowości budzi dostępność informacji o wszystkich transakcjach w systemie dla wszystkich użytkowników. Transakcje są jawne dla wszystkich, nieznana jest jednak tożsamość właścicieli poszczególnych adresów portfeli. Część badań skłania się z tego powodu ku poglądowi, że system Bitcoin zapewnia anonimowość (Ober, Katzenbeisser, \& Hamacher, 2013; Reid \& Harrigan, 2013). Znajomość wszystkich transakcji między wszystkimi portfelami rodzi jednak nowe możliwości analizy, także zautomatyzowanej z użyciem algorytmów kryminalistycznych, których nie dawał obrót gotówkowy. Należy wziąć także pod uwagę słabość czynnika ludzkiego oraz fakt, że finalnie BTC jest wymieniany na dobra materialne, które mogą pozwalać na ustalenie tożsamości właściciela portfela, z którego pochodziła transakcja (Koshy, Koshy, \& McDaniel, 2014). Te wątpliwości co do anonimowości w ocenie niektórych autorów kreują potrzebę utworzenia zmodyfikowanej wersji systemu Bitcoin zapewniającego pełną anonimowość (Bonneau i in., 2014; Miers, Garman, Green, \& Rubin, 2013).

Na marginesie należy wspomnieć, że otwartość oprogramowania (licencja typu open source), na podstawie którego działa system Bitcoin, umożliwia tworzenie podobnie działających systemów opartych o inne założenia.

\section{REGULACJA I KWALIFIKACJA PRAWNA KRYPTOWALUTY BITCOIN}

Kwalifikację prawną rozproszonych obliczeń dokonywanych przez komputery należące do systemu Bitcoin, w ramach krajowego porządku prawnego, utrudnia brak bezpośredniego odniesienia do kryptowalut w przepisach prawa. Ze względu na pojawiające się w obcych systemach prawnych regula- 
cje należy się spodziewać, że także w krajowym porządku prawnym zostanie ona w najbliższym czasie wypracowana. Jedną z pierwszych definicji legalnych zawiera regulacja zawarta w Arizona Revised Statutes, tytuł 44, rozdział 26, artykuł 5, litera E, punkt 1, zgodnie z którą przez „technologię łańcucha bloków” należy rozumieć technologię rozproszonego rejestru, która wykorzystuje rozproszony, zdecentralizowany, współdzielony i powielany rejestr, prywatny jak i publiczny, wymagający lub niewymagający uprawnień, uwierzytelniany przez token lub bez tokenu, w którym dane chronione są przez szyfrowanie, a także jest odporny na zmiany i transparentny oraz stanowi źródło prawdy.

Próbując określić, czy, a jeżeli tak, to jakim rodzajem prawa na gruncie systemu krajowego jest jednostka Bitcoin, napotykamy problem. Po analizie, dochodzi się bowiem do wniosku, że łatwiej jest określić, jakimi prawami Bitcoin nie są. Przede wszystkim nie stanowią one utworów w rozumieniu prawa autorskiego ze względu na brak autora; wszak są one generowane na podstawie odpowiednich algorytmów. Ta sama cecha wyłącza możliwość zakwalifikowania ich jako innych praw własności intelektualnej. Nie mogą być także zakwalifikowane jako rzeczy ze względu na brak postaci materialnej, a zgodnie z cywilistyczną definicją rzeczami mogą być tylko przedmioty materialne; jednostki Bitcoin nie mają lokalnego bytu, istnieją jako rozproszona po wszystkich węzłach systemu Bitcoin informacja o transakcji.

Mimo powyższych wniosków stoję na stanowisku, że jednostki Bitcoin należy zakwalifikować jako mienie. Zgodnie z definicją legalną mienia z przepisu art. 44 k.c. do mienia zalicza się własność i inne prawa majątkowe. W tym przypadku interesuje nas drugi składnik definicji mienia, czyli inne prawa majątkowe. Przepis nie definiuje zakresu pojęcia innych praw majątkowych, jednakże na gruncie orzecznictwa wykształciło się rozumienie praw majątkowych polegające na badaniu, czy dane prawo ma wartość majątkową w obrocie (por. uzasadnienie wyroku SN z dnia 9 marca 2004 r., sygn. akt I CK 425/03). Wojewódzki Sąd Administracyjny w Warszawie wypowiedział się jednoznacznie, że jednostki Bitcoin stanowią inne prawo majątkowe, jednakże rozstrzygając co do znaczenia tego pojęcia w rozumieniu ustawy z dnia 26 lipca 1991 r. o podatku dochodowym od osób fizycznych (por. uzasadnienie wyroku Wojewódzkiego Sadu Administracyjnego w Warszawie z dnia 
11 września 2015 r., sygn. akt III SA/Wa 3374/14). Rozstrzygnięcia wymaga więc nadal pytanie o możliwość zakwalifikowania jednostek Bitcoin jako prawa majątkowego w rozumienia przepisu art. 44 k.c.

W odniesieniu do jednostek Bitcoin można wskazać trzy przymioty, które uzasadniają kwalifikowanie go jako prawa majątkowego w rozumieniu przepisu art. 44 k.c. Pierwszym przymiotem jest jego wartość ekonomiczna, czyli powiązanie jednostek Bitcoin z interesem ekonomicznym danego podmiotu, którą można wykazać faktem zainteresowania jednostkami Bitcoin przez uczestników. Warto jednak pamiętać, że wartość ekonomiczna tych jednostek należy jednak do zagadnień kontrowersyjnych, głównie ze względu na istotne fluktuacje cen, które pozwalają wysuwać twierdzenia o spekulacyjnym charakterze tego instrumentu. Należy jednak zauważyć, że wahania cen kryptowalut związane są bardzo często $z$ informacjami dotyczącymi podjętych albo planowanych działań legislacyjnych, które mogą wpływać na obrót. W tym świetle, fluktuacje te wydają się uzasadnione naturalnymi obawami uczestników kształtującego się jeszcze rynku kryptowalut. Z tego względu, o ile nie wykluczam spekulacji na rynku kryptowalut, to nie podzielam poglądu o zupełnym braku wartości ekonomicznej jednostek Bitcoin. Drugim przymiotem uzasadniającym uznanie jednostek Bitcoin za prawo majątkowe jest możliwość posiadania ich z wyłączeniem innych osób. Wynika to z konstrukcji systemu, który uzależnia możliwość rozporządzania jednostkami Bitcoin od posiadania klucza prywatnego do danego portfela. Klucz prywatny stanowi więc zarówno środek dowodowy do wykazania posiadania jednostek Bitcoin, jak i środek techniczny umożliwiający rozporządzanie nimi w systemie. Trzecim przymiotem uzasadniającym uznanie jednostek Bitcoin za prawo majątkowe jest możliwość przenoszenia ich na inne osoby. Ze względu na powyższe cechy jednostek Bitcoin należy uznać stanowisko WSA w Warszawie za prawidłowe z punktu widzenia spójności systemowej. Uznanie jednostek Bitcoin za prawa majątkowe rodzi poważne konsekwencje na gruncie prawa cywilnego, włącznie z możliwością żądania ochrony posiadania na gruncie przepisów o czynach niedozwolonych oraz o bezpodstawnym wzbogaceniu. Na marginesie należy wspomnieć, że jednostki Bitcoin nie mogą być uznane za prawa o charakterze obligacyjnym, ponieważ nie da się wskazać drugiej strony takiego stosunku - wykazanie 
posiadania jednostek Bitcoin zależne jest od zapisów w rozproszonej bazie danych, która nie pozostaje w dyspozycji żadnego konkretnego podmiotu (chociaż możliwe jest występowanie świadczenia polegającego na przeniesieniu jednostek Bitcoin w stosunku obligacyjnym).

Wątpliwości prawne wzbudzał także charakter transakcji polegających na wymianie walut państwowych na jednostki Bitcoin. Pytanie to miało znaczenie głównie ze względu na związany z odpowiedzią na to pytanie obowiązek zapłaty podatku od towarów i usług. Uznanie wymiany BTC na pieniądze za transakcję finansową było przedmiotem interpretacji indywidualnych Ministra Finansów (por. m.in. pismo z dnia 21 czerwca 2013 r. Izba Skarbowa w Katowicach, IBPP2/443-258/13/ICz; pismo z dnia 14 listopada 2013 r. Izba Skarbowa w Katowicach, znak IBPP2/443-762/13/ICz; pismo z dnia 8 stycznia 2014 r. Izba Skarbowa w Poznaniu, znak ILPP1/443-912/13-2/AW; pismo z dnia 24 czerwca 2014 r. Izba Skarbowa w Warszawie, znak IPPP2/443-243/14-4/BH). W interpretacjach indywidualnych minister finansów uznał za nieprawidłowe stanowiska wnioskodawców uznające transakcje polegające na wymianie jednostek Bitcoin na jednostki pieniężne zwolnione z VAT usługi finansowe.

Doniosłe znaczenie dla prawnego rozumienia systemu Bitcoin, zwłaszcza w kontekście przytaczanych wyżej interpretacji indywidualnych ministra finansów, miał wyrok piątej izby Trybunału Sprawiedliwości z dnia 22 października 2015 r., Skatteverket v. David Hedqvist (C-264/14), w którym postanowiono, że art. 2 ust. 1 lit. c) dyrektywy Rady 2006/112/WE z dnia 28 listopada 2006 r. w sprawie wspólnego systemu podatku od wartości dodanej należy interpretować $\mathrm{w}$ ten sposób, że stanowią odpłatne świadczenie usług w rozumieniu tego przepisu transakcje, takie jak w postępowaniu głównym, polegające na wymianie waluty tradycyjnej na jednostki wirtualnej waluty Bitcoin i odwrotnie, dokonywane za zapłatą kwoty odpowiadającej marży wynikającej z różnicy między ceną, po jakiej dany przedsiębiorca nabywa waluty, a ceną, po jakiej je sprzedaje klientom. Ponadto postanowiono, że w świetle art. 135 ust. 1 lit. e) dyrektywy 2006/112 świadczenia usług, które polegają na wymianie walut tradycyjnych na jednostki wirtualnej waluty Bitcoin i odwrotnie, dokonywane za zapłatą kwoty odpowiadającej marży wynikającej z różnicy między ceną, po jakiej dany przedsiębiorca nabywa waluty, a ceną, po jakiej je sprzedaje klientom, stanowi transakcje zwolnione z podat- 
ku od wartości dodanej w rozumieniu tego przepisu. W związku z wyrokiem C-264/14 nastąpiła zmiana rozumienia transakcji wymiany jednostek Bitcoin na inne waluty, co jednocześnie wiąże się z uznaniem jednostek Bitcoin za alternatywny środek płatniczy (por. np. zmianę interpretacji indywidualnej Ministra Rozwoju i Finansów z dnia 19 stycznia 2017 r. Ministerstwo Finansów, znak PT8.8101.21.2016.WCX.64 lub uzasadnienie wyroku Wojewódzkiego Sądu Administracyjnego w Warszawie z dnia 7 kwietnia 2016 r., sygn. akt III SA/Wa 3453/15).

W roku 2017 dwa systemy prawne włączyły obrót kryptowalutami do zakresu zdarzeń regulowanych przepisami prawa. Prace nad regulacją japońską trwające od 2016 r. (Smart, 2016) dotyczyły w szczególności zawarcia regulacji związanych z publicznoprawną stroną bezpieczeństwa obrotu KYC/AML (przeciwdziałanie praniu pieniędzy i obowiązki dot. due diligence). Nacisk na tę stronę regulacji zapewne związany był z głośną sprawą Mt. Gox wspomnianą wyżej. Regulacja uznająca kryptowaluty za równorzędne tradycyjnym walutom weszła w życie z dniem 1 kwietnia 2017 r. Z prywatnoprawnego punktu widzenia uznaje ona kryptowaluty za środek płatniczy, a także pozwala na księgowanie kryptowalut zarówno po stronie pasywów, jak i aktywów (Das, 2017).

Regulacja uchwalona w stanie Arizona (Arizona House Bill 2417 an Act Amending Section 44-7003, Arizona Revised Statutes; Amending Title 44, Chapter 26, Arizona Revised Statutes, by Adding Article 5; Relating to Electronic Transactions z dnia 29 marca 2017 r.) w sposób kompleksowy reguluje prywatnoprawne zagadnienia związane $\mathrm{z}$ obrotem kryptowalutami. Podpis złożony w rejestrze prowadzonym za pomocą technologii łańcucha bloków uważany jest za równoważny z podpisem elektronicznym, a zapis lub kontrakt zawarty za pośrednictwem łańcucha bloków uważany jest za kontrakt zawarty w formie elektronicznej. Regulacja wprowadza także dyrektywę interpretacyjną kontraktów, która zakazuje uznania kontraktu za nieskuteczny, nieważny lub nienadający się do wykonania ze względu na obecność w nim postanowień o tzw. sprytnych kontraktach definiowanych jako sterowany zdarzeniami program stanowy, operujący na rozproszonym, zdecentralizowanym, współdzielonym i powielanym rejestrze, którym to rejestrem może zarządzać i wydawać instrukcje przeniesienia na nim aktywów (ang. „smart contract" means an event-driven program, with state, that runs on a distributed, decen- 
tralized, shared and replicated ledger and that can take custody over and instruct transfer of assets on that ledger). Definicja ta zawiera wszystkie elementy konieczne do posługiwania się sprytnymi kontraktami na gruncie aktów prawnych. Wskazuje ona na to, że jest to program sterowany zdarzeniami, to znaczy, że po uruchomieniu programu konieczne jest nastąpienie zdarzeń, które spowodują uruchomienie odpowiednich funkcji w tym programie. Zdarzenia te, podobnie jak ugruntowane $\mathrm{w}$ tradycji cywilistycznej warunek i termin, mogą mieć charakter pewny lub niepewny. Program ten jest charakteryzowany jako program stanowy (w przeciwieństwie do programu bezstanowego), czyli taki, który zachowuje informację o operacjach wykonanych w przeszłości. Program stanowy „pamięta” wykonane działania, a także zdarzenia, które wywołały funkcje tego programu. W definicji zawarto też cechy łańcucha bloków, na którym program jest wykonywany. Cechy te wyłączają stosowanie łańcuchów bloków prywatnych (przepis wymaga, aby rejestr był zdecentralizowany), czyli takich, które używane są przez wyłącznie jeden podmiot. W definicji znajduje się także wymóg, aby program mógł dokonywać operacji na łańcuchu bloków i dokonywać przenoszenia aktywów na nim zapisanych. Słowo „aktywa” też jednoznacznie wskazuje na związek sprytnego kontraktu z zasobami ekonomicznymi, stąd definicja ta nie uznaje za sprytny kontrakt np. programu uruchomionego na testowym łańcuchu bloków. Na marginesie należy wspomnieć, że definicja ta zawiera w sobie nie tylko czynności polegające na przenoszeniu kryptowalut, lecz pozwala także na włączenie do stosunku umownego bardziej bogatych programów komputerowych, które będą decydować o prawach i obowiązkach stron; szersze omówienie tego tematu wykracza jednak poza ramy niniejszej publikacji.

\section{Podsumowanie}

Stworzenie „cyfrowego złota” w postaci rozproszonego rejestru zwanego łańcuchem bloków stanowi i z pewnością będzie jeszcze przez najbliższe lata stanowić źródło wyzwań. Wyzwania te należą do trudnych ze względu na konieczność wyważenia w projektowanych regulacjach między interesem publicznym i interesem prywatnym. Regulacje obrotu i istoty kryptowalut można podzielić na kilka grup. W pierwszej grupie znajdziemy systemy, w których brak jest regulacji wprost odnoszących się do kryptowalut, jednakże ogólne 
zasady systemu prawa pozwalają na ustalenie stosunku systemu prawnego do obrotu kryptowalutami. W tej grupie znajdował się polski system prawny do momentu wydania orzeczenia Skatteverket v. David Hedqvist (C-264/14), które ustaliło sposób interpretacji przepisów unijnych w tym zakresie. Przykład ten pokazuje, że w systemach nieposiadających przepisów wprost odnoszących się do kryptowalut ich kwalifikacja prawna nie musi być jednolita. Drugą grupę stanowią systemy prawne, w których regulacja jest szczątkowa i odnosi się zwykle do konkretnego aspektu obrotu kryptowalutami. Takimi systemami są obecnie systemy prawne państw Unii Europejskiej, w których przesądzona zbliżona do pieniądza rola kryptowalut na mocy orzecznictwa Trybunału Sprawiedliwości Unii Europejskiej. Trzecią grupę stanowią systemy, w których regulacja kryptowalut jest kompleksowa w taki sposób, że uregulowane są zarówno skutki czynności z użyciem kryptowalut, ustalona jest natura kryptowalut (traktowana jako pieniądz, towar lub inny rodzaj instrumentu). Te systemy prawne, wykazując najbardziej progresywne podejście, z pewnością będą w przyszłości źródłem interesującego orzecznictwa i źródłem inspiracji porównawczej. W końcu nie można pominąć systemów prawnych, w których obrót kryptowalutami jest zakazany. Ta wąska grupa systemów przejawia najbardziej zachowawcze podejście do tych nowych instrumentów. Podejście to może wydawać się jednak w przypadku tych państw rozsądne ze względu na specyficzne uwarunkowania ekonomiczne, które są niezbędne, aby korzystać z pozytywnych stron obrotu kryptowalutami. W przypadku państw nieuczestniczących w globalnej gospodarce niewykluczone jest, że zachowawcze podejście stanowi najrozsądniejszą politykę państwa względem kryptowalut.

\section{Literatura}

Bonneau, J., Narayanan, A., Miller, A., Clark, J., Kroll, J.A., \& Felten, E.W. (2014). Mixcoin: Anonymity for Bitcoin with accountable mixes, [w:] International Conference on Financial Cryptography and Data Security (p. 486-504), Springer, http://link. springer.com/chapter/10.1007/978-3-662-45472-5_31 [dostęp: 27.12.2017].

Ciućkowska-Leszczewicz, K. (2013). Odpowiedzialność wspólników spótki cywilnej. Prawo rzymskie a tradycja współczesnego prawa prywatnego, Olsztyn: Wydział Prawa i Administracji Uniwersytetu Warmińsko-Mazurskiego. ISBN 9788362383412. 
Das, S. (2017, marzec 29). Bitcoin in Japan: Officially Recognized in April; Asset or Expense?, CryptoCoinsNews, https://www.cryptocoinsnews.com/bitcoin-injapan-officially-recognized-in-april-asset-or-expense/ [dostęp: 27.12.2017].

Koshy, P., Koshy, D., \& McDaniel, P. (2014). An analysis of anonymity in bitcoin using p2p network traffic, [w:] International Conference on Financial Cryptography and Data Security (s. 469-485), Springer, http://link.springer.com/chapter/10.1007/978 -3-662-45472-5_30 [dostęp: 27.12.2017].

Luo, G.Y. (1998). The evolution of money as a medium of exchange, „Journal of Economic Dynamics and Control" 23(3), 415-458. ISSN 0165-1889.

Marian, O.Y. (2013). Are Cryptocurrencies „Super” Tax Havens?, „Michigan Law Review First Impressions" 38, 112. ISSN 0026-2234.

Mariański, M. (2015). Problematyka kwalifikacji prawnej wirtualnej waluty we Francji, „Państwo i Prawo”, 10, s. 92-100. ISSN 0031-0980.

Miers, I., Garman, C., Green, M., \& Rubin, A.D. (2013). Zerocoin: Anonymous distributed e-cash from bitcoin, [w:] Security and Privacy (SP), 2013 IEEE Symposium on (p. 397-411), IEEE, http://ieeexplore.ieee.org/xpls/abs_all.jsp?arnumber=6547123 [dostęp: 27.12.2017].

Mittal, S. (2012). Is Bitcoin Money? Bitcoin and Alternate Theories of Money (SSRN Scholarly Paper No. ID 2434194), Rochester, NY: Social Science Research Network, http://papers.ssrn.com/abstract=2434194 [dostęp: 27.12.2017].

Nakamoto, S. (2008). Bitcoin: A peer-to-peer electronic cash system, „Consulted”, $1(2012), 28$.

Ober, M., Katzenbeisser, S., \& Hamacher, K. (2013). Structure and anonymity of the bitcoin transaction graph. „Future internet” 5(2), p. 237-250. ISSN 1999-5903.

Reid, F., \& Harrigan, M. (2013). An analysis of anonymity in the bitcoin system, [w:] Security and privacy in social networks (p. 197-223), Springer, http://link. springer.com/chapter/10.1007/978-1-4614-4139-7_10 [dostęp: 27.12.2017].

Sitek, B. (2016). Unifikować czy synchronizować prawo w Europie? Studium przypadku od prawa rzymskiego do prawa europejskiego, „Journal of Modern Science” 2(29), s. 109-130.

Smart, E. (2016). Japan Officially Recognizes Bitcoin and Digital Currencies as Money, https://bitconnect.co/bitcoin-news/130/japan-officially-recognizes-bitcoin-anddigital-currencies-as-money [dostęp: 13.05.2017].

Włodarczyk, B. (2014). Komu służy system finansowy? - refleksja po światowym kryzysie gospodarczym, „Studia i Prace Kolegium Zarządzania i Finansów SGH” 140, s. 179-188. ISSN 1234-8872. 